\title{
A FIRST ACCOUNT OF FRESHWATER POTAMOLEPID SPONGES (DEMOSPONGIAE, SPONGILLINA, POTAMOLEPIDAE) FROM THE MIDDLE EOCENE: BIOGEOGRAPHIC AND PALEOCLIMATIC IMPLICATIONS
}

\author{
ANDRZEJ PISERA, ${ }^{1}$ PETER A. SIVER, ${ }^{2}$ AND ALEXANDER P. WOLFE ${ }^{3}$ \\ ${ }^{1}$ Institute of Paleobiology, Polish Academy of Sciences, ul.Twarda 51/55, 00-818 Warszawa, Poland, <apis@twarda.pan.pl>; \\ ${ }^{2}$ Connecticut College, Botany Department, New London, Connecticut 06320, USA, <passive@connel.edu>; and ${ }^{3}$ Department of Earth and \\ Atmospheric Sciences, University of Alberta, Edmonton, AB T6G 2E3, Canada <awolfe@ualberta.ca>
}

\begin{abstract}
Aвstract - We report the oldest fossil occurrence of freshwater potamolepid sponges (Demospongiae, Spongillina, Potamolepidae) to date, originating from middle Eocene lake sediments accumulated in the Giraffe kimberlite maar, northern Canada. Sponges are represented by strongyle spicules that are gemmuloscleres. These are described herein as belonging to a new species, Potamophloios canadensis. Because the most similar extant potamolepid sponges inhabit subtropical to tropical water bodies, these observations provide further evidence of biogeographic reorganizations in response to warm high-latitude Eocene paleoclimates.
\end{abstract}

INTRODUCTION

$\mathrm{M}$ OST OF the over 8,000 living species of sponges are marine (Hooper and Van Soest, 2002), augmented by a large number of fossil taxa (Hooper et al., 2011). In contrast, there are only about 200 species of freshwater sponges, attributed to six families and 45 genera, all of which belong to the class Demospongiae (Manconi and Pronzato, 2008). Only 18 species are known from freshwater habitats in Europe (Pronzato and Manconi, 2001), whereas modern North American freshwater sponges are represented by 27 species in 11 genera (Frost et al., 2001). The highest diversity of freshwater sponges is found in the Neotropics, especially in South and Central America and the Caribbean, with 56 species in 21 genera (Manconi and Pronzato, 2008). The diversity of freshwater sponges is probably underestimated in many regions due to a paucity of studies, as testified by the number of new taxa revealed from regions that were thought to have been thoroughly investigated (Manconi and Pronzato, 2005; Volkmer-Ribeiro et al., 2009, 2010; Nicacio et al., 2011; Ruengsawang et al., 2012).

Marine demosponges appear in the Neoproterozoic (i.e., 555$600 \mathrm{Ma}$, Reitner and Woerheide, 2002) and have a relatively continuous fossil record since the Cambrian (Pisera, 2006; Hooper et al., 2011 and references therein). In contrast, the fossil record of freshwater sponges consists of only a few genera and species from shorter and often isolated time-slices separated by lengthy barren intervals (Pisera and Saez, 2003). The oldest freshwater sponges, reported from Permo-Carboniferous lake deposits in Europe (Schindler et al., 2008), are represented by simple oxeas forming spiculites. A similar type of preservation is associated with the Late Jurassic freshwater sponge Eospongilla morrisonensis from the western U.S. (Dunagan, 1999).

The earliest record of well preserved freshwater sponges includes intact gemmules (resting bodies) from the Lower Cretaceous of South America (Ott and Volkheimer, 1972; Volkmer-Ribeiro and Reitner, 1991). The Paleogene record of freshwater sponges is better represented with findings from several continents (see Pisera and Saez, 2003 and references therein). Eocene freshwater sponges, in particular, are relatively well documented from European sites including the famous Messel oil shales (Müller et al., 1982; Richter and Wuttke, 1995,
1999), and the Eckfeld maar (Gruber, 1994). The former locality has yielded a range of new taxa, including Ephydatia guttenbergiana (Müller et al., 1982) and Lutetiospongilla heili (Richter and Wuttke, 1999). Additionally, the species Ephydatia kaiseri (gemmulae observed in thin section) has been described from the "prämitteleozäne" of South Africa (Rauff, 1926; Arndt, 1936).

Today, freshwater sponges are found on all continents except Antarctica and occur in an extremely wide range of habitats (Manconi and Pronzato, 2002, 2008). Some species have apparent cosmopolitan distributions, but there are equally as many endemic forms restricted to ancient freshwater bodies, such as Lake Baikal and lakes of the East African rift (Manconi and Pronzato, 2002, 2008; Meixner et al., 2007). In this paper, we report the first occurrence of a fresh-water siliceous potamolepid demosponge from the middle Eocene, and describe it as a new species. These microfossils provide new constraints on the evolution of this sponge lineage by extending their geological range considerably, and furthermore provide ancillary paleoecological evidence for the character of high-latitude lake ecosystems under equable climatic conditions.

GEOLOGICAL SETTING

The Giraffe fossil locality (Nowicki et al., 2004; Wolfe et al., 2006; Siver and Wolfe, 2009; Doria et al., 2011) comprises an organic sediment sequence that accumulated post-eruptively in a kimberlite diatreme having intruded the Slave Craton of the Canadian Shield 47.8 \pm 1.4 Ma (Fig. 1). Immediately following kimberlite phreatomagmatism, a water body formed in the crater, and limnic sediments began to accumulate. It is difficult to estimate the dimensions of the lake, but comparisons to similar kimberlites on the Ekati diamond property suggest a diameter between 100 and $200 \mathrm{~m}$. There is no evidence of multiple phreatomagmatic events. Approximately $50 \mathrm{~m}$ of lacustrine sediment (laminated shales and massive organic mudstones with occasional presence of nodular opal-A) comprise the lower maar facies, which is succeeded by terrestrial sediments dominated by Metasequoia (Coniferae, Cupressaceae) foliage and wood. Two calc-alkaline airfall tephra layers occur at the transition between lacustrine and terrestrial sedimentation. These ashes have been dated by 


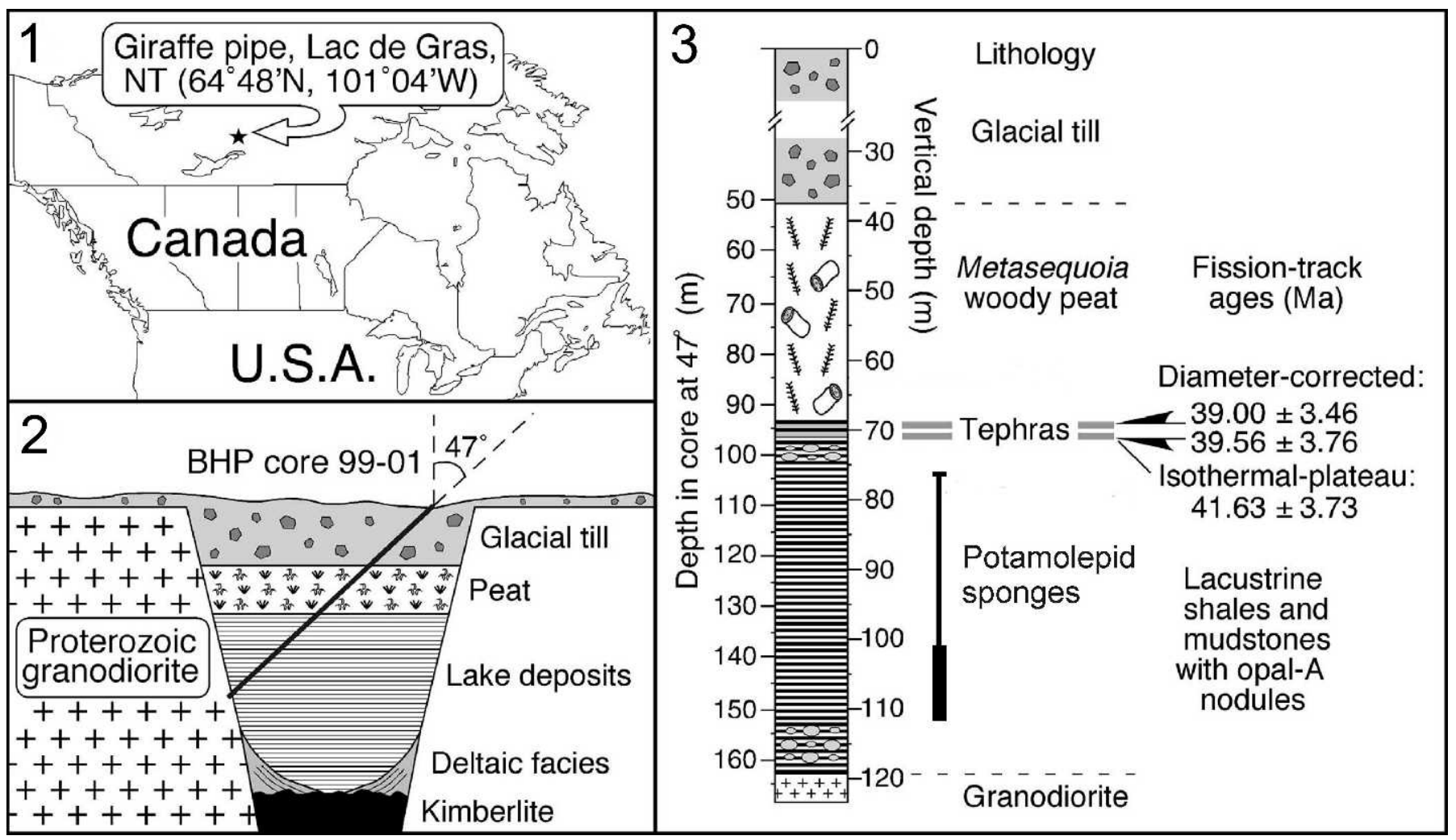

FiguRE 1-Location map and stratigraphy of the Giraffe fossil locality. 1 , location; 2, schematic stratigraphy; 3 , lithostratigraphy and potamolepid sponges occurrences. The width of the vertical bar indicates the relative abundance of sponge spicules.

fission-track analysis, yielding concordant dates that produce a weighted mean of $37.84 \pm 1.99$ Ma (Doria et al., 2011). This implies that the entire lacustrine sequence is middle Eocene (Lutetian Stage) in age. Due to the thermal and tectonic stability of the locality, diagenetic alteration of fossil material is minimal, and accordingly all organism groups investigated thus far display outstanding preservation (Wolfe et al., 2006; Siver and Wolfe, 2009; Siver et al., 2010).

\section{MATERIAL AND METHODS}

The investigated material originates from a drill-core obtained in 1999 by BHP Billiton Diamonds Inc. during diamond exploration. The core was collared at $47^{\circ}$ but depths reported here have been converted to their vertical equivalents (Fig. 1). The present study is based on isolated spicules obtained from sediment samples $(\sim 200 \mathrm{mg}$ ) following treatment with $30 \%$ $\mathrm{H}_{2} \mathrm{O}_{2}$, repeated washings with deionized water, and final suspension in reagent grade propanol (isopropyl alcohol). Resulting suspensions were dried onto a microscope cover glass, attached with carbon glue to an SEM stub, sputter coated with platinum, and examined with a Phillips XL20 SEM (Institute of Paleobiology, Warsaw) at magnifications from $\times 100$ to $\times 5,000$ and a voltage of $25 \mathrm{kV}$. Among the 48 examined samples, those from the interval $97.39 \mathrm{~m}$ in the core $(71.23 \mathrm{~m}$ vertical equivalent depth) to $153.30 \mathrm{~m}$ in the core $(112.12 \mathrm{~m}$ vertical depth) revealed abundant sponge spicules. The investigated material is curated in the collection of the Institute of Paleobiology, Polish Academy of Sciences, Warszawa, Poland, under the accession number ZPAL Pf. 23.

\section{RESULTS}

In a general sense, most of the samples rich in sponge spicules also contain diverse diatom (Bacillariophyceae), chrysophyte
(Chrysophyceae and Synurophyceae) and euglyphid (Euglyphidae, Rhizaria) assemblages, many of which retain pronounced affinities with modern taxa (Siver and Wolfe, 2005, 2009). Numerous morphotypes of birotule and non-birotule gemmuloscleres (spicules forming an armour of the resting bodies), as well as microscleres, were recognized, together representing a highly diversified assemblage of freshwater sponges.

The identification of freshwater sponges, as is the case with other siliceous sponge groups, is based on the character and organization of spicules, including megascleres, microscleres and gemmuloscleres. Megascleres are similar in many species of freshwater sponges, however gemmuloscleres are highly diagnostic at the species level, and isolated specimens can be used to identify specific taxa in a fossil sample even if the whole sponge is not preserved.

The Giraffe material contains a rich diversity of freshwater sponges with 14 or more species documented to date (Pisera et al., 2008; Pisera, 2010). The majority belongs to the family Spongillidae Gray 1867, including the cosmopolitan genus Ephydatia, and will be described in detail elsewhere. The present paper focuses on remains of spicules representing the family Potamolepidae Brien 1967 (Figs. 2, 3), including the description of a new species.

\section{SYSTEMATIC PALEONTOLOGY}

Class Demospongiae Sollas, 1885

Family Potamolepidae Brien, 1967

Genus Potamophloios Brien, 1970

Type species._Potamolepis stendelli Jaffe, 1916.

Diagnosis.-After Manconi and Pronzato (2002), Potamolepidae with large body size $(50-15 \mathrm{~cm})$ ranging from encrusting to massive and lobate. Color from gray to dark gray. Consistency 


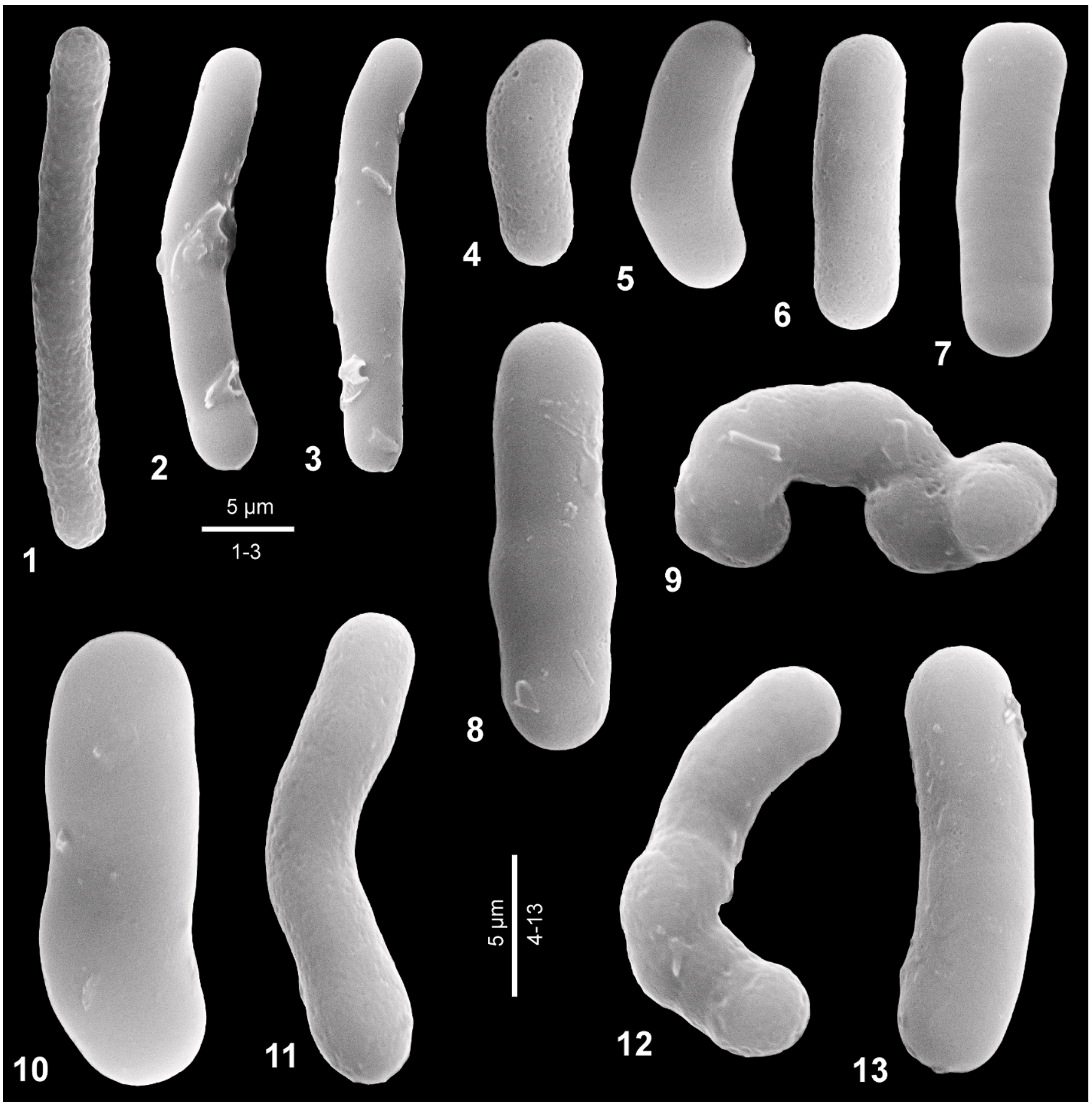

Figure 2-Patomophloios canadensis n. sp., type material from $110.83 \mathrm{~m}$ depth in the Giraffe core, ZPAL Pf. 23/A395. Gemmulosclere strongyles.

hard. Surface irregular with conules. Ectosomal skeleton with tangential small oxeas. Choanosomal skeleton dense alveolate with a more open network in the basal portion. Megascleres stout smooth strongyles with inflated ends but also more slender strongyles are present. Microscleres oxeas as dermal spicules. Gemmules single or grouped, from subspherical to oval or hemispherical when strictly adhered to the substratum. Foramen primitive with a simple inconspicuous concavity. Theca monolayered of compact spongin. Gemmuloscleres smooth to spined, elongated to oval strongyles.
Potamophloios CANADENSIS new species

Figures 2, 3

Diagnosis.-Patomophloios characterized by gemmuloscleres that are smooth strongyles of small and highly variable shape and size, often bent, curved or irregular.

Description.-Material studied includes loose spicules on SEM stubs (ZPAL Pf.23/A105, A395).The spicules are smooth, thick, strongyles with highly variable dimensions (Figs. 2, 3). Spicules are often curved, bent, or otherwise slightly irregular. Many specimens have inflated tips. Their size range is from 7.90-30.9 $\mu \mathrm{m}$ long $\times 3.12-5.0 \mu \mathrm{m}$ wide (Figs. 2, 3). We recognize, however, 


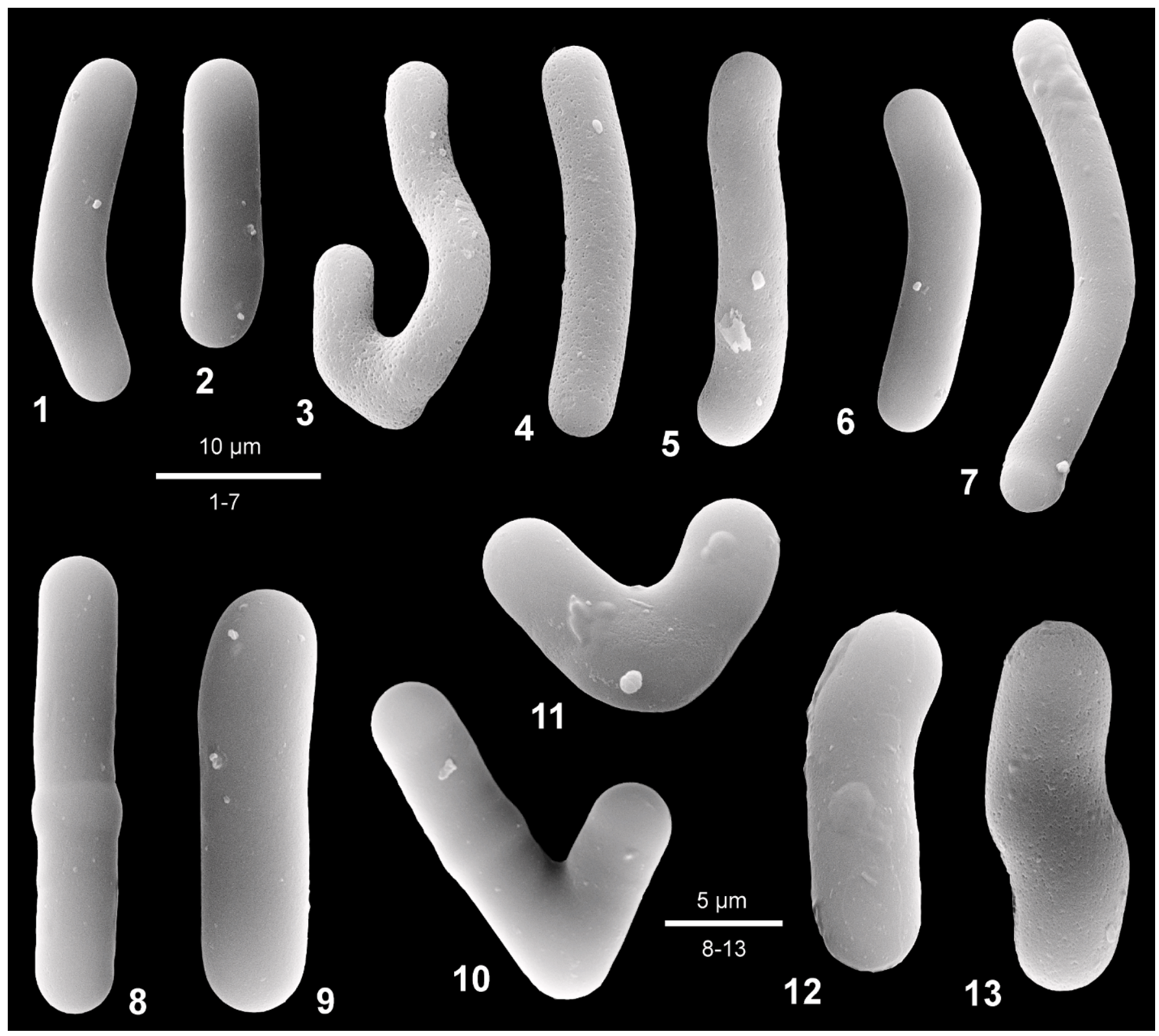

Figure 3-Patomophloios canadensis n. sp. from $112.12 \mathrm{~m}$ depth in the Giraffe core, ZPAL Pf.23/A105. Gemmulosclere strongyles.

that similar large size differences also characterize modern potamolepid sponges (Manconi and Pronzato, 2010; VolkmerRibeiro et al., 2010). Microscleres are absent.

Etymology.- Referring to Canada, where the sponge was found.

Type specimens.-The collection of specimens on SEM stub A395 (collection number ZPAL Pf. 23/A395), here illustrated on Figure 2.

Occurrence.-Middle Eocene (Lutetian) lake sediments, Giraffe kimberlite maar, northern Canada, $\left(64^{\circ} 44^{\prime} \mathrm{N}, 109^{\circ} 45^{\prime} \mathrm{W}\right)$.

Remarks. - Highly variable abundances of spicules attributed to potamolepid sponges were observed in the Giraffe Pipe core from vertical depths between $112.12 \mathrm{~m}$ and $76.93 \mathrm{~m}$. The greatest concentrations occurred between $112.12 \mathrm{~m}$ and $101.10 \mathrm{~m}$, and again at $76.93 \mathrm{~m}$, close to the transition from aquatic to terrestrial environments, when the lake was shallowing.

Spicules of similar morphology to the smooth and thick strongyles observed in the Giraffe material occur not only in the family Potamolepidae, but also in other recent spongillids such as the genus Corvospongilla Annandale, 1911 (Manconi and Pronzato, 2004, 2009; Ruenswang et al., 2012). For example, $C$. mesopotamica and $C$. thysii can have similar megascleres and gemmuloscleres but these species also produce oxea megasclere and microsclere spicules that were not observed in the Giraffe samples containing numerous gemmular strongyles. The species Corvospongilla siamensis Manconi and Ruengsawang (Ruengsawang et al., 2012) described from Thailand has gemmuoscleres of similar morphology but they are adorned with spines and never have inflated ends. This species is also characterized by micropseudobirotule microscleres.

Strongyles and oxea megascleres, which may represent megascleres of newly described species, occur in some samples higher up in the core. However, the sample from $110.83 \mathrm{~m}$ contains numerous small strongyles, interpreted as gemmulosclers, and no other types of spicules. The fact that we observed only gemmuloscleres, and not megasleres in this sample (the most rich in the discussed spicules) may suggest selective transport of 
various sponge components. On the other hand, the absence of any microscleres that are of similar size suggests that the investigated sponges lacked microscleres, which matches the characteristics of Potamolepidae. In fact, even if microscleres that belong to other genera occur in various samples higher up in the core, none of them can be attributed to the genus Corvospongilla. Thus, we conclude that the source organism was characterized by strongyles as gemmuloscleres, with no microscleres, consistent with our designation of a new species within the family Potamolepidae. Due to the fact that possible megascleres of this species occur in multispecific assemblage of spicules, their unequivocal attribution to this new species is not currently possible because similarly shaped megascleres may occur in other genera. The strongyle spicules observed in this study are very small, much more so than any observed in modern representatives of the family. The small size is unlikely attributable to low ambient silica concentrations, because the presence of primary opal-A nodules and significant concentrations of other siliceous microfossils suggest that silica concentrations were replete. Lastly, in cases when the strongyles co-occur with other sponge spicules, the latter show no evidence of size reduction. We conclude that the investigated spicules belong to a species in the genus Potamophloios (see Manconi and Pronzato, 2009; Volkmer-Ribeiro et al., 2010), but as noted they are smaller and always completely smooth compared to known species in the genus. Taking into account the size differences and morphological characters, as well as their Eocene age, we conclude that these spicules belong to a new species of the genus Potamophloios Brien, 1970, and not Corvospogilla Annandale, 1911.

\section{DISCUSSION}

To this point, the only known and therefore oldest fossil potamolepid sponge is Oncosclera kaniensis from what are likely early Miocene fluvial sediments from Japan (Matsuoka and Masuda, 2000). This and other occurrences have been cited as evidence for a Gondwanan origin of the family (VolkmerRibeiro and Rosa-Barbosa, 1978; Volkmer-Ribeiro, 2007; Erpenbeck et al., 2011). The findings reported here not only refute this notion but also extend the fossil record of Potamolepidae by approximately 20 million years, to at least the middle Eocene.

At present, representatives of the Potamolepidae occur only in Africa (four genera), the Neotropics (three genera), the Pacific Oceanic Islands (one genus) (Manconi and Pronzato, 2002), and Indochina (one genus) (Manconi et al., 2012). The family is thus strongly restricted to tropical climate regimes, with no known temperate, boreal, or polar occurrences (Manconi and Pronzato, 2002, 2009). The presence of potamolepid sponges near the Arctic Circle in northern Canada during the middle Eocene therefore confirms a near-tropical climate state during deposition of lake sediments in the Giraffe maar. This idea supports previous findings based on remains of tropical chrysophytes and diatoms (Siver and Wolfe, 2009) that co-occur with the potamolepid sponge spicules in these sediments, collectively indicating a warm, subtropical to tropical climate, with markedly reduced seasonality and the absence of frost.

As is true of most freshwater sponges, living potamolepid sponges are characteristic of lakes and rivers and require firm substrates, such as rocks, wood fragments or plants, for colonization (Frost et al., 2001; Manconi and Pronzato, 2002, 2009). Pinheiro (2007) reported that the potamolepid genera Oncosclera, Sterrastolepis and Uruguaya from Brazil required hard substrata, typically rock or concrete, and some Onclosclera species may grow on bamboo sticks (Manconi et al., 2012). One species, Oncosclera spinifera, inhabits very shallow $(<20 \mathrm{~cm}$ deep) water with temperature $30^{\circ} \mathrm{C}$ and $\mathrm{pH}=7$. Numerous wellpreserved spicules have been uncovered from the Giraffe core, but to date no whole intact gemmules have been found. Given that gemmules have a relatively high preservation potential (Pisera and Saez, 2003), it is possible that the sponges inhabited the rocky walls of the crater margin rather than the sediment surface itself, and that spicules were preferentially transported to the soft sediment as disarticulated elements, facilitated by the fact that the gemmular structure in potamolepids is based largely on siliceous spicules while spongin is very scanty (R. Manconi, personal commun.).

\section{CONCLUSIONS}

Middle Eocene lacustrine sediments from the Giraffe fossil locality are rich in siliceous microfossils with remarkable preservation, among them sponge spicules that we interpret as gemmuloscleres referrable to the family Potamolepidae. Small and smooth strongyles were found throughout much of the core, with the highest concentrations near the top of the lacustrine facies that captures shallowing of the limnic environment prior to terrestrialization. Because modern potamolepid sponges have pronounced tropical affinities, these observations offer yet another bioindicator supporting the notion of biogeographic reorganizations during the warm climatic conditions that characterized northern Canada during the middle Eocene. This discovery further extends the known age range of the family Potomalepidae by $\sim 20 \mathrm{Ma}$, which is directly relevant to better constraining the phylogeny of freshwater sponges as a whole.

\section{ACKNOWLEDGMENTS}

This study was financed by the Institute of Paleobiology, Polish Academy of Sciences, to A. Pisera, the National Science Foundation (grants DEB-0716606 and DEB-1144098) to P. Siver, and a Natural Sciences and Engineering Research Council of Canada Discovery Award to A. Wolfe. We would like to thank R. Manconi (Sassari) and M. Wuttke (Mainz) for critical remarks.

\section{REFERENCES}

Annandale, N. 1911. Freshwater Sponges, Hydroids and Polyzoa. Porifera, p. 27-126, 241-245. In A. E. Shipley (ed.), Fauna of British India, including Ceylon and Burma. Taylor and Francis, London.

Arndt, W. 1936. Die von Dr. A. Monard in Angola gesammelten Suswasserschwamme. Mit einem Uberblick uber die Spongilliden-fauna Africas nach dem gegenwartigen Stand unserer Kentnisse. Arquivos do Museu Bocage, 7:7-35.

Brien, P. 1967. Éponges du Luapula et du Lac Moero, p. 1-52. In J. J. Symoens (ed.), Exploration hydrobiologique du Lac Bangweoloet du Luapula: Résultats Scientifiques. Cercle hydrobiologique de Bruxelles, 11(1).

Brien, P. 1970. Les Potamolépides africaines. Polyphylétismedes Eponges d'eau douce. Archives de Zoologie expérimentale et générale, 110:527-561

Doria, G., D. L. Royer, A. P. Wolfe, A. Fox, J. A. Westgate, and D. J. BeERLING. 2011. Declining atmospheric $\mathrm{CO}_{2}$ during the late middle Eocene climate transition. American Journal of Science, 311:63-75.

Dunagan, S. P. 1999. A North American freshwater sponge (Eospongilla morrisonensis new genus and species) from the Morrison Formation (Upper Jurassic), Colorado. Journal of Paleontology, 73:389-393.

Erpenbeck, D., T. Weier, N. J. de Voogd, G. Wörheide, P. Sutcliffe, J. A. TodD, AND E. Michel. 2011. Insights into the evolution of freshwater sponges (Porifera: Demospongiae: Spongillina): barcoding and phylogenetic data from Lake Tanganyika endemics indicate multiple invasions and unsettle existing taxonomy. Molecular Phylogenetics and Evolution, 61: 231-236

Frost, T. M. 2001. Freshwater sponges, p. 253-262. In J. P. Smol, H. J. B. Birks and W. M. Last (eds.), Tracking Environmental Change Using Lake Sediments. Volume 3: Terrestrial, Algal, and Siliceous Indicators. Kluwer Academic Publishers, Dordrecht, The Netherlands.

Frost, T. M., H. Reiswig, and A. Ricciardi. 2001. Porifera, p. 97-133. In J. H. Throp and A. P. Covich (eds.), Ecology and Classification of North American Freshwater Invertebrates, 2nd edition. Academic Press, San Diego. 
Gruber, G. 1994. Kieselschwammm-Nadeln aus dem Mitteleozane des Eckerfelder Maares, Eifel (Porifera: Demospongiae: Spongillidae). Mainzer naturwisseschaftlischer Archiv, 32:1-6.

Hooper, J. N. A. And R. W. M. Van Soest (eds.).2002. Systema Porifera: a guide to the classification of sponges. Kluwer Academic/Plenum Publishers, New York, 1708 p.

Hooper, J. N. A., R. W. M. Van Soest, and A. Pisera. 2011. Phylum Porifera Grant, 1826, p. 13-18. In Zhang, Z.-Q. (ed.), Animal biodiversity: An outline of higher-level classification and survey of taxonomic richness. Zootaxa, 3148

JAFF́, G. 1916. Zwei Schwämme aus dem Tanganjikasee (Spongilla moorei Evans und Potamolepis stendelli n. sp.). Zoologischer Anzeiger, 48 (3):514.

Manconi, R. and R. Pronzato. 2004. The genus Corvospongilla Annandale (Haplosclerida, Spongillina, Spongillidae) with description of a new species from eastern Mesopotamia, Iraq. Archive fur Hydrobiologie: Supplements, 151/1-2, Monographic studies, p. 161-189.

Manconi, R. and R. Pronzato. 2008. Global diversity of sponges (Porifera: Spongillina) in freshwater. Hydrobiologia, 595:27-33.

Manconi, R. and R. Pronzato. 2002. Spongillina n.suborder, Lubomirskidae, Malawispongiidae n. fam., Metaniidae, Metschnikowiidae, Paleospongillidae, Potamolepiidae, Spongillidae, p. 921-1019. In H. J. N. Hooper and R. W. M. Van Soest (eds.), Systema Porifera: A Guide to the Classification of Sponges, Vol. 1. Kluwer Academic/Plenum Publishers, New York.

Manconi, R. and R. Pronzato. 2005. Freshwater sponges of the West Indies: discovery of Spongillidae (Haplosclerida, Spongillina) from Cuba with biogeographic notes and a checklist for the circum-Caribbean area. Journa of Natural History, 39:3235-3253.

Manconi, R. and R. Pronzato. 2009. Atlas of African freshwater sponges. Studies in Afrotropical Zoology, 295:1-214.

Manconi, R., N. Ruengsawang, F. D. Ledda, C. Hanjavanit, and N. SANGPRADUB. 2012. Biodiversity assessment in the Lower Mekong basin first record of the genus Oncosclera (Porifera: Spongillina: Potamolepidae) from the Oriental Region. Zootaxa, 3544:41-51.

Matsuoka, K. And Y. Masuda. 2000. A new potamolepid freshwater sponge (Demospongiae) from the Miocene Nakamura Formation, central Japan. Paleontological Research, 4:131-137.

Meixner, M. J., C. Lüter, C. Eckert, V. Itskovich, D. Janussen, T. von Rintelen, A. V. Bohne, J. M. Meixner, and W. R. Hess. 2007. Phylogenetic analysis of freshwater sponges provide evidence for endemism and radiation in ancient lakes. Molecular Phylogenetics and Evolution, 45: 875-886.

Müller, W. E. G., R. K. ZAhn, AND A. Maidhof. 1982. Spongilla guttenbergiana n.sp. ein Suswasserschwamm aus dem Mittel-Eozane von Messel. Senckenbergiana Lethea, 63:465-472.

Nicacio, G., W. Severt, and U. Pinheiro. 2011. New species of Radiospongilla (Porifera: Spongillidae) from Brazilian inland waters. Zootaxa, 3132:56-63.

Nowicki, T., B. Crawford, D. Dyck, J. Carlson, R. McElroy, P. Oshust, and H. Helmstaedt. 2004. The geology of kimberlite pipes of the Ekati property, Northwest Territories, Canada. Lithos, 76:1-27.

Ott, E. AND W. Volkheimer. 1972. Paleospongilla chubutensis n. g. et n. sp. Ein Süsswasserschwamm aus der Kreide Patagoniens. Neues Jahrbuch für Geologie und Paläontologie Abhandlungen, 140:49-63.

PinheIRo, U. Dos SANTos. 2007. Contribuições a Taxonomia e Biogeografia das Esponjas de Águas Continentais Brasileiras. Unpublished thesis, UFRJ, Museu Nacional, Rio de Janeiro, 233 p.

PiserA, A. 2006. Palaeontology of sponges - a review. Canadian Journal of Zoology, 84:242-261.

Pisera, A. 2010. A high diversity Middle Eocene freshwater sponge fauna from the Giraffe Pipe crater lake, Canada. VIII World Sponge Conference 2010, Girona, Book of Abstracts, 93.
Pisera, A. And A. Saez. 2003. Paleoenvironmental significance of a new species of freshwater sponge from the Late Miocene Quillagua Formation (N. Chile). Journal of South American Earth Studies, 15:847-852.

Pisera, A., P. Siver, And A. Wolfe. 2008. Middle Eocene freshwater sponges from Canada: preliminary report. Ninth Paleontological Conference, Warszawa, Abstracts, 70-71.

Pronzato, R. and R. Manconi. 2001. Atlas of European freshwater sponges. Annali Museo Civico Storia Naturale Ferrara 4:3-64

RAUFF, H. 1926. Über prämitteleozäne fossilfuhrende Süswasser-Hornsteine aus der Namib. p. 160-166. In E. Kaiser (ed.), Die Diamantenwuste Südwest-Afrikas, Bd. 2. D. Deimer, Berlin

Reitner, J. And G. Woerheide. 2002. Non-Lithistid fossil DemospongiaeOrigins of their palaeobiodiversity and highlights in history of preservation, p. 52-68. In H. J. N. Hooper and R. W. M. Van Soest (eds.), Systema Porifera: A Guide to the Classification of Sponges, Vol. 1. Kluwer Academic/Plenum Publishers, New York.

Richter, G. and M. WuttKe 1995. Der Messel Suüsswasser-Kieselschwamm Spongilla gutenbergiana, eine Ephydatia. Natur und Museum 125:134-135.

Richter, G. AND M. Wuttke. 1999. Lutetiospongilla heili n. gen. n. sp. und die eozäne Spongillidefauna von Messel. Courier Forschung-Institute Senckenberg, 216:183-195.

Ruengsawang, N., N. Sangpradub, C. Hanjavanit, and R. Manconi. 2012. Biodiversity assessment of the Lower Mekong Basin: a new species of Corvospongilla (Porifera: Spongillina: Spongillidae) from Thailand. Zootaxa, 3320:47-55.

Schindler, T., M. Wuttke, and M. Poschmann. 2008. Oldest record of freshwater sponges (Porifera: Spongillina) spiculite finds in the PermoCarboniferous of Europe. Paläontlogische Zeitschrfit, 82:373-384.

Siver, P. A., J. M. Pelczar, A. M. Lott, And A. Pisera. 2010. The Giraffe Pipe database project: a web-based database for siliceous microfossils from a freshwater Eocene waterbody. Proceedings of the Seventh International Chrysophyte Symposium New London, Connecticut, June 2008. Nova Hedwigia Beihefte, 136:325-331.

Siver, P. A. AND A. P. Wolfe. 2005. Eocene scaled chrysophytes with pronounced modern affinities. International Journal of Plant Sciences, 166 533-536.

Siver, P. A. And A. P. Wolfe. 2009. Tropical ochrophyte algae from the Eocene of Northern Canada: a biogeographical response to past global warming. Palaios, 24:192-198

Sollas, W. J. 1885. A Classification of the sponges. Annals and Magazine of Natural History 5, 16(95):395.

VolkMER-RiBeiro, C. 2007. South American continental sponges: state of the art of the research. Porifera Research: Biodiversity, Innovation and Sustainability-M. R. Custódio, G. Lôbo-Hajdu, E. Hajdu, G. Muricy (eds.), Série Livros 28. Museu Nacional, Rio de Janeiro.

Volkmer-Ribeiro, C. And R. De Rosa Barbosa. 1978. A new genus and species of neotropical freshwater sponges. Iheringia. Série Zoologia, 52:103-107.

Volkmer-Ribeiro, C. AND J. Reitner. 1991. Renewed study of the type material of Paleospongilla chubutensis Ott and Volkheimer (1972), p. 121133. In J. Reitner and H. Keupp (eds.), Fossil and Recent Sponges, Springer, Berlin.

Volkmer-Ribeiro, C., M. da Conceiçao, M. Tavares, and K. Fürstenau de Oliveira. 2009. Acanthothyra alvarenagai (Porifera, Demospongiae) new genus and species of sponge from Tocantins Rivers, Pará State, Brasil. Iheringia, Serie Zoologia, 99:345-348.

Volkmer-Ribeiro, C., M. Parolin, K. Furstenau-Oliveira, and W. R. de Menezes. 2010. Colonization of hydroelectric reservoirs in Brazil by freshwater sponges, with special attention on Itaipu. Interciencia, 35:340 347.

Wolfe, A. P., M. B. Edlund, A. R. Sweet, and S. D. Creighton. 2006. A first organelle preservation in Eocene nonmarine diatoms: observation and paleobiological implications. Palaios, 21:298-304.

Accepted 3 December 2012 